\title{
ON THE CATION UPTAKE MECHANISM OF SPHAGNUM MOSSES
}

\author{
VILjo PuUstjärvi \\ Department of Agricultural Chemistry, University of Helsinki
}

Received December 5, 1958

Several different theories have recently been presented in relation to the adsorption of nutrition by plants. All these theories have one point in common viz, that no one theory has been able simultaneously to explain the uptake of cations and anions. Indeed, it is probably a generally accepted contention that the cation and anion uptakes occur entirely independently of each other, by means of completely different mechanisms. The following considerations will be restricted to dealing with the cation uptake of plants only.

According to present notions, the roots obtain their cations from the surfaces of soil particles with the aid of carbonic acid. The roots are assumed to secrete carbon dioxide, which forms carbonic acid on its solution in water. The carbonic acid molecules subsequently travel into the immediate vicinity of the soil particles, where the hydrogen ions dissociated by the carbonic acid are exchanged against the cations in the soil particles. The base bicarbonate then returns into the immediate vicinity of the roots, where it is retained in the root as such, i.e., as a pair of ions, e.g. $\mathrm{K}^{+}+\mathrm{HCO}_{3}{ }^{-}$, or in such a manner that a hydrogen ion secreted by the root is exchanged against the base ion of the bicarbonate. The latter of the two lastmentioned alternatives is considered more likely.

Differing with the general opinion described abore, JENNy and OvERSTreET (2) have presented a theory according to which the cation exchange takes place between roots and soil particles in immediate contact with each other, i.e. without any participation in the reaction of the electrolytes in the soil solution.

Among the numerous investigations relating to the cation uptake of the roots, which have greatly contributed to the advance of knowledge in this field, should also be mentioned the investigations of LUNDEGÅRDH and MATTSON, which are closely associated with the subject matter of the present investigation. According to LUNDEGÅRDH (7), an electrical potential difference exists between the roots and the soil particles and in his opinion it controls the cation uptake of the roots. Under laboratory conditions he has even succeeded in measuring this potential difference. 
MATtSON and KarLsson (9), again, have paid attention to the acid character of the roots, upon which the cation uptake of the roots is based in their opinion.

In the investigations concerning the nutrition uptake of plants, exchange capacities of the roots and the nutrient quantities adsorbed by the roots from various substrates have been determined, whereas no attention seems to have been paid in the literature to the base equilibrium prevailing between the roots and the soil particles. If it is postulated that the roots adsorb bases according to the principle of cation exchange, then one may assume that it is the base equilibrium which determines the cation uptake of the roots. The base equilibrium in turn is determined, except by the adsorbed bases, also in accordance with the quantity of exchangeable hydrogen ions. However, it has to be admitted that the study of the said equilibrium relations may cause considerable difficulties in actual practice. One should keep in mind that the cation exchange occurs between the soil particles and the outermost cell layer of the roots. For obvious reasons it is fairly difficult, if not impossible, to isolate the outermost cell layer, or rather its cellulose membrane coming into contact with the soil, which has a thickness varying between 0.1 and $3.0 \mu$ according to LUNDEGÅRDH (7). The investigation might also be made so as to deal with the roots in their entirety, assuming only their outermost wall to be involved in the reactions as has been done, for instance, in the determination of the exchange capacities of the roots. In that way one might perhaps achieve qualitative though hardly any quantitative results, since the activities of the investigated colloids as calculated per unit weight would not be mutually comparable.

The objective of the present investigation is to attempt a determination of the equilibrium relations between the plant roots in contact with the soil and the colloids in the soil, and by this approach to throw some light upon the nutrient adsorption of the plants. Sphagnum mosses were chosen as the material of investigation. This was done because their cells are comparatively little specialized to serve different purposes. It is well-known that Sphagnum mosses take their nutrition from the soil by means of their leaves which have the thickness of only one cell layer, the mass of their leaves frequently constituting the main part of the entire plant's mass. Moreover, they possess an exceptionally high exchange capacity (11) and grow on a substrate with an exchange capacity of the same order of magnitude as that of the moss (12). Of course, even this approach cannot be expected to lead to quantitative results in regard to the cation exchange capacity, nevertheless satisfactory results may be reached in so far that they can serve as a basis for inferences with regard to the nutrition adsorption of Sphagnum mosses.

Since the Sphagnum mosses, which mainly belong to the plant communities of bogs, are not plants generally known, a short description is given in the follonwing of their anatomic structure (6). This has been done because the peculiar anatomic structure of these plants forms the foundation for the theory of the working hypothesis presented in this investigation.

The structure of the Sphagnum moss can be seen in Fig. 1. The most essential parts of the plant are its stem and leaves. In the stem (Fig. 2) three different kinds of cellular tissue are distinguished: pith, wood, and bark. The vascular bundle lacking in the Sphagnum mosses is replaced by the pith tissue, which is assumed 


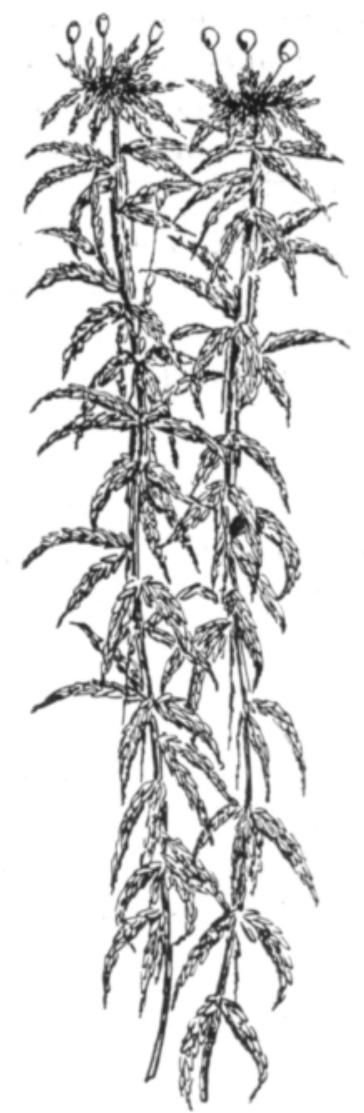

Fig. 1 Sphagnum moss; natural size. (PAAsio, 10).
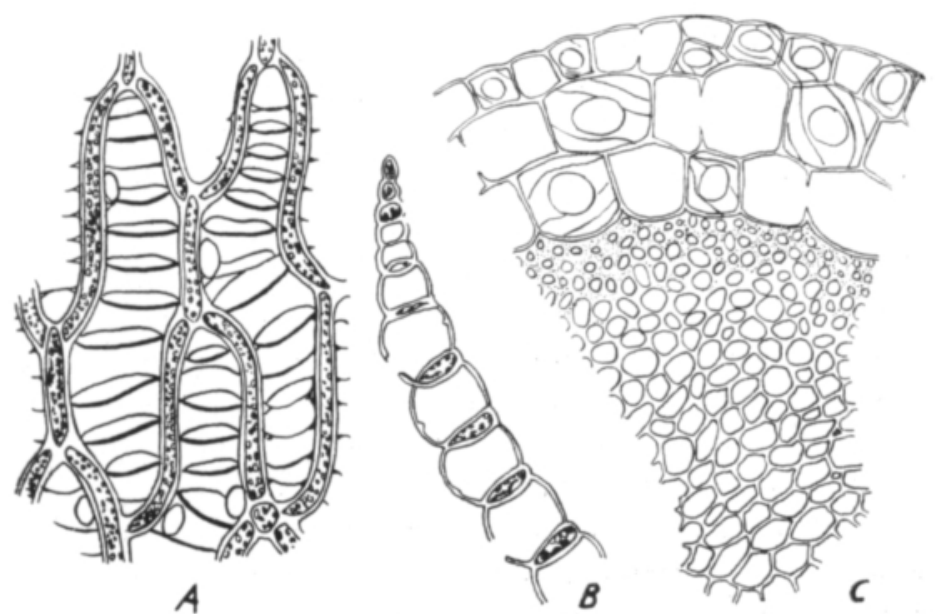

Fig. 2 Sphagnum moss. A. Cellular tissue of leaf $(300 / 1)$, B. Part of leaf in cross section (300/1), C. Part of stem in cross section $(120 / 1)$. (PAAsio, 10). 
to act both as a nutrient transport medium and as a storage place of reserve nutrition. The wood tissue lends the plants the required support. The bark is built up of 1 to 4 cell layers, which are believed to be acting as recipients of water and the nutrients dissolved in it, and as their transporter to the top parts of the plant.

The leaves may be either stem or branch leaves. They are formed of a single cell layer and have no vascular bundle. Their cellular tissue consists either of chlorophyllous or chlorophyll-less, living cells and of dead cells containing air or water. The living cells form a network, in the meshes of which the latter are located.

From the point of view of the investigation, particular attention has to be paid to two points in the structure of the Sphagnum mosses.

1. The Sphagnum mosses have no root cell tissue specialized in absorbing water and nutrients; instead, they take up their nutrients with the aid of those parts that are buried in the peat and which have exactly the same anatomic structure as the assimilating superterrestrial parts. Sphagnum mosses grow without any limit at their upper end, while the lower parts die and are humified to peat. The parts of the Sphagnum mosses buried in the substrate thus functionally correspond to the roots of higher plants.

2. The colloid content of the Sphagnum mosses is exceptionally high. According to a certain series of material, their exchange capacity varied between $86-$ $148 \mathrm{me} / 100 \mathrm{~g}$ (11). The corresponding figures for the roots of higher plants derived from a fairly extensive material varied between $9.0-58.9 \mathrm{me} / 100 \mathrm{~g}(1)$.

댄.

\section{Theoretical}

In order to solve the problem which has been set as the aim of this investigation, it would obviously be most appropriate to study only those parts of the moss and of the peat that come into contact with each other. In actual practice, however, it would have been impossible to isolate the material of investigation in this manner, nor is this actually necessary. Reference has already been made to the fact that the parts of the moss coming into contact with the peat have an anatomic structure exactly similar to that of its higher parts. There is no reason to presume that also the colloidal properties of the moss might not be the same in its various parts. Local variations may occur but on an average the moss is similar in character at any given point. The effect of the local variations can be minimized by taking a sample of adequate size. The reactions occurring at the boundary surfaces between moss and peat, again, tend to achieve equilibrium in the other parts of the system as well. The system as a whole thus tends to attain a certain state of equilibrium. There is consequently no reason to expect any great margin of error if, instead of the membranes on the boundary surfaces, both participants in the system, i.e., the peat and the moss, are studied in their entirety. It is conceivable, however, that if the upper parts of the moss plant are very far from the parts buried in the peat, there may exist potential differences in the equilibrium between its upper and lower parts. This question will be discussed later.

If the moss takes up bases from the peat in accordance with the cation exchange 
principle, it must exchange bases from the peat with hydrogen ions. In the case of higher plants the hydrogen ion dissociated by carbonic acid has been thought to be acting as an intermediate in this process. Taking into account the anatomic structure of the Sphagnum mosses and their high colloid content, it seems simpler to assume that the hydrogen ions dissociated by the colloidal acids in the moss, the so-called acidoids, are immediately exchanged against the base cations of the peat. JENNY (1939) has shown that the plant roots and the clay particles may be so close to each other that cation exchange between the outermost membrane of the roots and the clay colloids is possible. There is no reason to presume that the same phenomenon might not be at least equally well possible in the case of mosses and peat colloids.

Cation exchange can be thought as taking place without any noteworthy energy changes although energy changes are associated with this phenomenon. When higher plants take nutrients from the soil with the aid of their roots, the required energy is believed to be derived from a combustion process. This, again, presupposes the presence of oxygen. Several mosses grow in peat where the presence of oxygen is limited to a very thin surface layer (8). Being plants without vascular bundle, the mosses have difficulties in obtaining oxygen even within the scope of their own system. The fact remains that the transfer of cations from the peat into the moss requires energy, which it is difficult on the basis of the foregoing to explain as being derived from a combustion process in which molecular oxygen is involved.

Mention has already been made of the acidoids in the peat and of the hydrogen ions dissociated by them, which probably originate mainly from carboxyl groups. These active hydrogen ions impart a certain electrical charge to the moss, the amount being determined by the activity of the hydrogen ions. The peat, too, contains dissociated hydrogen ions, which for their part give the peat a certain charge. If the electrical charges in the moss and in the peat are unequal, a certain electrical potential difference is produced at the boundary surface, its magnitude being dependent on the activities of the hydrogen ions in the moss and in the peat. Mathematically, a potential difference of this kind can be expressed by the formula

$$
\mathrm{E}=\frac{\mathrm{RT}}{\mathrm{nF}} \ln \frac{\left[\mathrm{H}^{+}\right] \text {moss }}{\left[\mathrm{H}^{+}\right] \text {peat }}
$$

where $\mathrm{E}$ is the said potential difference and $\left[\mathrm{H}^{+}\right]$denotes the activity of the respective hydrogen ions.

The potential difference between the moss and the peat tends to become equalized. This is possible by means of part of the base cations in the peat passing over from the peat into the moss, provided that $\left[\mathrm{H}^{+}\right]$moss $>\left[\mathrm{H}^{+}\right]$peat, since reactions in nature tend to take a course whereby a lesser amount of energy contained in the system will result.

Thus, in order that the moss should be able to take cations from the peat, the activity of its hydrogen ions should be higher than the corresponding activity in the peat. In the peat the activity of the hydrogen ions is determined by its exchange capacity and by the quantity of base cations retained in exchangeable form. This 
also applies to Sphagnum mosses. However, new acidoids are continuously being formed in their points of growth, and these acidoids can be taken to be saturated with hydrogen ions in their stage of nascence. According to what has been said before, there will then obtain a potential difference between the point of growth and the parts below this point. The potential difference consequently forces base cations to move from older parts of the moss plant to its younger parts. Sooner or later this transfer of base cations to the point of growth also manifests itself as a potential difference on the boundary surface between moss and peat. This, in turn, effects a transfer of bases from the peat into the moss. Since new acidoids saturated with hydrogen ions are continuously formed in the points of growth, this will produce a continuous, although slow, flow of bases from the peat to the points of growth of the moss. In higher plants the nutrients are assumed to travel with the water in the vascular bundles towards the higher parts of the plant. According to the considerations here presented, it is not necessary to assume such a free movement of the bases in Sphagnum mosses inasmuch as their transport inside the plant can also be tought as taking place according to the principle of cation exchange in the direction of the potential difference and at a velocity determined by this potential difference.

\section{Methods}

In order to be able to study the validity in practice of the working hypothesis presented above, one should be able to determine the hydrogen ion concentrations in the moss as well as in the peat. The most direct approach to the objective would of course be immediate measurement of the potential difference. In this investigation, however, it was decided to choose the analytical way, as it was desired to study the phenomenon from the viewpoint of cation exchange. It can be assumed that it is possible to establish the potential difference existing between the moss and the peat in its principal features even by this approach, employing Nernst's formula, which has been referred to in the foregoing.

The activities appearing as arguments in NERNST's formula cannot be determined analytically. However, since only comparatively dilute solutions are concerned, the concentrations can be considered sufficiently accurate approximations of the activities. The acidoids of the peat and of the moss being weak acids, the quantity of active hydrogen ions in them is a function of their $\mathrm{pH}$. Therefore, the hydrogen ion concentrations have been determined from titration curves in this investigation; the curves were obtained by titration of the samples in question in a 1-n $\mathrm{BaCl}_{2}$ solution with 0.1-n $\mathrm{NaOH}$.

In comparing the titration curves of moss and peat, it is possible immediately to see the quantity of exchangeable hydrogen ions in both at the respective $\mathrm{pH}$ of the peat, which prevailed at the time of sampling.

The base content of the soil can be determined by the same method. If the bases are removed from the samples prior to titration, e.g. by means of washing with hydrochloric acid, the titration curve will reveal the highest possible hydrogen ion concentration, or the exchange capacity at a given $\mathrm{pH}$. By comparing with 
each other, in one and the same reaction, the exchange capacity, i.e., the highest possible hydrogen ion concentration, and the corresponding hydrogen ion concentration that prevailed at equilibrium, their difference is established as the quantity of hydrogen ions that has been exchanged for base cations, or at the same time also as the quantity of base cations. It should be noted that the total base quantity obtained in this way, which has been denoted by $\mathrm{S}_{T}$ in this investigation, also includes iron and aluminium in addition to the strong bases, since these cations, too, are retained in the peat or in the moss by exchange against hydrogen ions.

For the sake of clarity it should, moreover, be mentioned that in this investigation the samples washed with hydrochloric acid, or saturated with hydrogen ions, have been indicated by means of the prefix $\mathrm{H}$, i.e. $\mathrm{H}$ peat and $\mathrm{H}$ moss. The samples not subjected to hydrochloric acid treatment are called samples in their natural state. The moss is denoted by the letter $\mathrm{m}$ and the peat forming its substrate by $\mathrm{p}$. The samples in their natural state have been given the subindex 1, i.e. $\mathrm{m}_{1}$ and $\mathrm{p}_{1}$, the $\mathrm{H}$ samples having the index 2, i.e. $\mathrm{m}_{2}$ and $\mathrm{p}_{2}$. These notations have been used particularly in the figures.

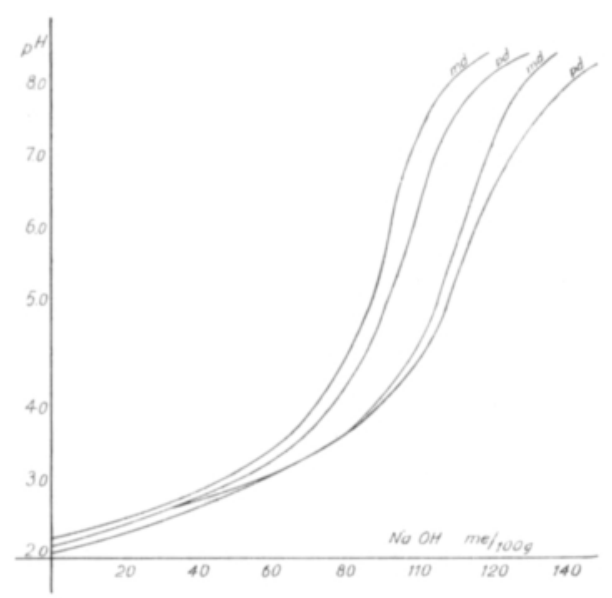

Fig. 3 Titration curves of fresh (f) and dry (d) moss (m) and peat (p) samples.

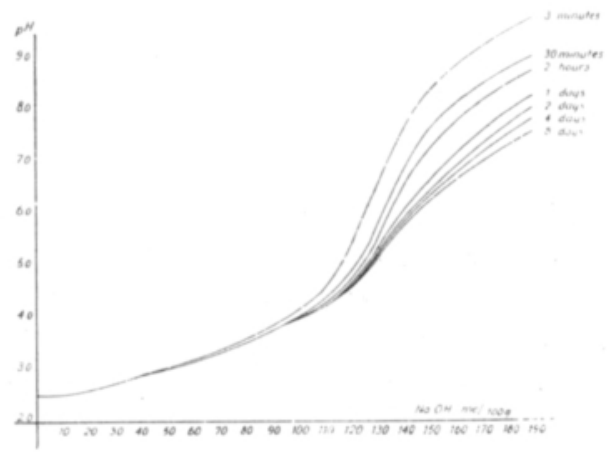

Fig. 4 Effect of titration rate upon the shape of the titration curve. 
When peat or moss is being used as material of investigation, it is comparatively difficult, if not totally impossible, to obtain a titration curve reflecting the true state of the matter. This is due to disturbing side reactions occurring during titration.

Already during the drying of the samples there occur reactions which affect the shape of the curve. It would appear most expedient to titrate the fresh samples, but it is difficult to obtain from them a homogeneous part representing the entire growth base. In order to counteract this difficulty, an attempt was made at the gathering of the samples to take samples only from such points were the peat showed the greatest possible homogeneity. Several pairs of fresh as well as dried moss and peat samples were titrated all results showing the same trend. Fig. 3 gives an example of the curve series obtained. It can be seen that the strength and exchange capacity of the acidoids has gone down slightly under the effect of drying and that the differences have increased with an increasing $\mathrm{pH}$. On the other hand the mutual relations of the moss and peat samples did not undergo any noteworthy changes due to the drying of the samples. It is therefore of no great concern from the viewpoint of this investigation whether the titration is carried out with fresh or dried samples, since similar results are obtained in both instances. The majority of the samples were titrated in the fresh state and, for the sake of control, frequently in the dried state as well.

The side reactions occurring during titration prove to be a great nuisance in their effect upon the shape of the titration curve, causing considerable sources of error. The longer the duration of titration, the greater is also the influence of the side reactions. It would thus be most advantageous to perform the titration as quickly as possible. On the other hand the titration has to be carried out at a rate slow enough to allow for the exchange reactions. Several titrations were performed at varying rates in order to find the most favourable rate of titration. Equal quantities of the substance to be titrated were weighed into several flasks and increasing quantities of $\mathrm{NaOH}$ were added. The first $\mathrm{pH}$ reading was made 3 minutes after the base addition and subsequent readings at certain intervals, at which the flasks were shaken. Fig. 4 shows one of the curve series obtained in this manner. It can be seen that the titration curves become less steep with a decreasing rate of titration. The higher the initial $\mathrm{pH}$, the greater is also the descent of the reaction. The phenomenon may be due, for instance, to the oxydation of weak phenolic hydroxyl groups into strong carboxyl groups (MATTson 1942), or also to the activation of the carboxyl groups liberated as a result of ester saponification (KELLER and DEUEL 1957).

It can be seen from Fig. 4 that the titration curves begin to diverge approximately only above $\mathrm{pH}$ 4. This is probably attributable to the fact that below the said reaction there occurs only cation exchange, which takes place rapidly, and the side reactions do not begin to affect the course of titration until above $\mathrm{pH}$ 4. In order to minimize the disturbing influence from the side reactions, the titrations reported in this work were performed in the rapid modification. The readings were made 3 minutes after the addition of base.

In addition to the total base content $\left(\mathrm{S}_{T}\right)$, also the ash alkalinity $\left(\mathrm{S}_{a}\right)$ has been 


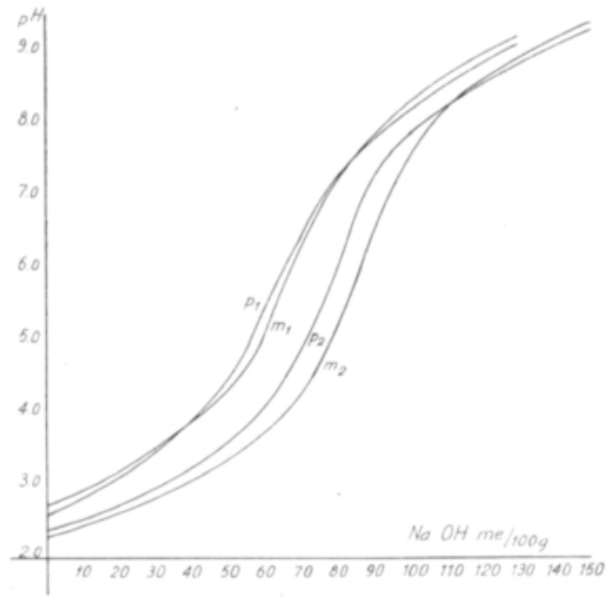

Fig. 5 Titration curves of S. cuspidatum $(\mathrm{m})$ and of the Scheuzeria-Sphagnum peat $(\mathrm{p})$ constituting its growth base. 1. Untreated sample, 2. Sample washed with $\mathrm{HCl}$.

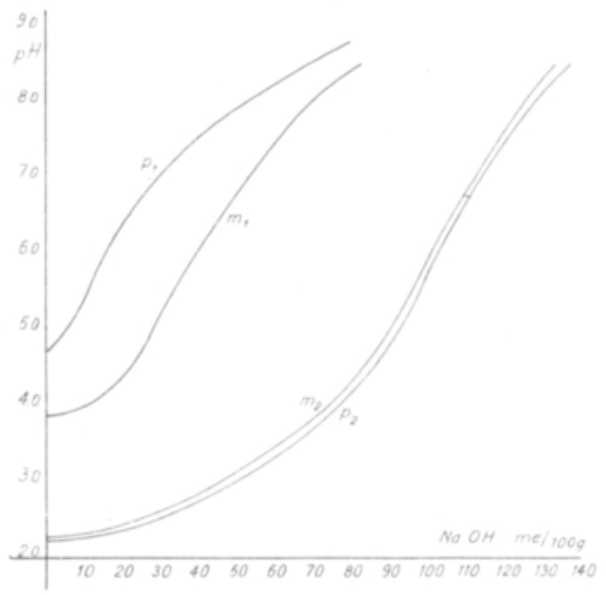

Fig. 6 Titration curves of S. Warnstorfianum $(\mathrm{m})$ and of the forest peat $(\mathrm{p})$ constituting its growth base.

determined as the $\mathrm{HCl}$ titration result of the ashes suspended in ammonium acetate. This quantity is approximately equivalent to the combined quantity of exchangeable strong base cations (13).

\section{Results}

For the determination of the base equilibrium of mosses and their substrates, about 60 pairs of moss and peat samples were investigated. The material had been collected in various parts of the country from as many different bog types as possible. In the material the trophicity series of quality classes of 1 to 10 and a growth substrate moisture series from "rimpi» bogs to the driest raised bogs were represented. Particular pains were taken to select such objects where the peat would be as highly humified as possible and where it would consist mainly of the residues of other 
plant species rather than the moss species under investigation. In the following only a few examples of the relatively extensive material of investigation will be presented. This is also considered sufficient, the majority of the samples in the entire material yielding the same result.

Fig. 5 shows a highly typical result of investigation representing watery, oligotrophic bog types. The samples - S. cuspidatum and Scheuzeria-Sphagnum peat - have been taken from a sedge bog growing Scheuzeria. A study of the curves in Fig. 5 reveals their great resemblance to the titration curves of dibasic weak acids. The hydrogen ions of the first phase of dissociation are probably hydrogen ions dissociated by the carboxyl groups. In this investigation the study has been limited to the first phase of dissociation since under the conditions of reaction prevailing in the bog only this phase has immediate significance in the cation uptake of the mosses. In order to express the strength of the colloidal acids in question, the dissociation constants were calculated for the material of investigation. With a few exceptions they were of the order of magnitude of $\mathrm{K}_{1}=7 \times 10^{-4}$.

The titration curves of the hydrogen ion-saturated $\mathrm{H}$ samples $\left(\mathrm{m}_{2}\right.$ and $\left.\mathrm{p}_{2}\right)$ express the ability of moss and peat to compete for possession of the cations. It can be seen from Fig. 5 that moss and peat are approximately matched in this respect, although moss is a slightly stronger competitor than peat. If bases are now introduced into this imaginary growth substrate saturated with hydrogen ions, the moss should retain them in a slightly higher proportion than the peat, owing to the higher hydrogen ion concentration of the moss. It can indeed be seen from the titration curves of the samples in their natural state that in a state of equilibrium both curves run quite closely together.

As a basis of the titration curves the dry matter weights of moss as well as of peat were used in the calculations. If both proved to have the same degree of moisture and the hydrogen ion concentrations were sufficiently accurate approximations of their activities, it would be possible, by means of NERNsT's formula, to calculate the potential difference between moss and peat on the basis of the curves. According to Fig. 5 there is scarcely any potential difference at all in the state of equilibrium. In practice this implies that the transfer of bases from the peat into the moss is rather slow, and thus the growth of the moss plant is also very slow.

In the following compilation, the base contents (in me/100 g) of the moss and peat from the preceding example are given as total base contents $\left(\mathrm{S}_{T}\right)$ and as ash alkalinity $\left(\mathrm{S}_{a}\right)$.

$\begin{array}{ccc} & \mathrm{S}_{T} & \mathrm{~S}_{a} \\ \text { S. cuspidatum } & 23 & 23 \\ \text { Scheuzeria-Sphagnum peat } & 17 & 16\end{array}$

The compilation reveals that both base forms are about equal in quantity. Only the peat shows a slight deviation, probably caused by iron and aluminium occurring in an exchangeable form. However, the difference was slightly bigger in a larger part of the investigated material, particularly as regards peat, and this is probably primarily due to the reason already mentioned. 
As an opposite to the bog type discussed above, the oligotrophic sedge bog, one may consider the pine bog of fen type. The titration curves of S. Warnstorfianum and of forest peat taken from this bog type are persented in Fig. 6. In this case the acidoids of moss and peat are equal in strength. In equilibrium, however, the hydrogen ion concentration of the moss is higher than that of the peat. This produces a potential difference on the boundary surface between moss and peat, which is found to have the following maginitude in the reaction in the natural state (at $\mathrm{pH}$ 6):

$$
\mathrm{E}=\frac{\mathrm{RT}}{\mathrm{nF}} \ln \frac{40}{26}=23 \mathrm{mV}
$$

A potential difference of this size is obviously able to maintain a considerable transport of bases from the peat into the moss and at the same time to further the increment growth of the plant. It is indeed understandable that on the pine bog of fen type the rate of growth of the mosses, as well as that of other plants, is of another order of magnitude than on the oligotrophic sedge bog.

The following compilation gives the base contents of the samples discussed in the foregoing.

$\begin{array}{lcc} & \mathrm{S}_{T} & \mathrm{~S}_{a} \\ \text { S. Warnstorfianum } & 61 & 60 \\ \text { Forest peat } & 87 & 62\end{array}$

$\mathrm{S}_{T}$ and $\mathrm{S}_{a}$ are again equal in the moss but the peat probably already contains considerable quantities of exchangeable iron and aluminium.

Fig. 7 shows the titration curves of S. subfulvum and of sedge peat, taken from a mesotrophic "rimpi» bog. A peculiarity of this instance is the considerably greater strength of the acidoids in the moss as compared with those of its growth base. The logical consequence should be that the moss has to be able to absorb relatively large quantities of bases from a substrate comparatively poor in bases. This has indeed occurred, as can be seen from the compilation below, and it explains why the base content of sedge-dominated peats is lower than expected in view of the trophicity (13).

$\begin{array}{lll} & \mathrm{S}_{T} & \mathrm{~S}_{a} \\ \text { S. subfulvum } & 62 & 55 \\ \text { Sedge peat } & 40 & 28\end{array}$

In the manner described above, the potential difference (E) between moss and peat is found to be $10 \mathrm{mV}$ in the case of the mesotrophic "rimpi» bog, which is considerably lower than for the pine bog of fen type but still of another order of magnitude than for the oligotrophic sedge bog, where the potential difference was almost zero.

The spruce-hardwoods peat moor type of South-Finland, the Myrtillus sprucehardwoods peat moor, is represented by the curves in Fig. 8 . Here the acidoids of the peat are exceptionally strong $\left(\mathrm{K}_{1}=2,2 \times 10^{-3}\right)$, which is obviously due to the high lignin content of the peat containing wood residues in abundance. Unusually strong are also the acidoids of the moss, S. Girgensohnii $\left(\mathrm{K}_{1}=2,0 \times 10^{-3}\right)$.

The potential difference between moss and peat is found to be $8 \mathrm{mV}$ in this case and the base contents are: 


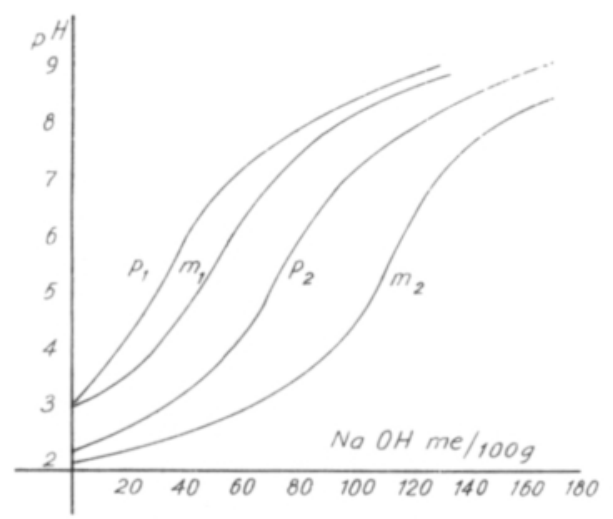

Fig. 7 Titration curves of S. subfulvum $(\mathrm{m})$ and of the sedge peat (p) constituting its growth base.

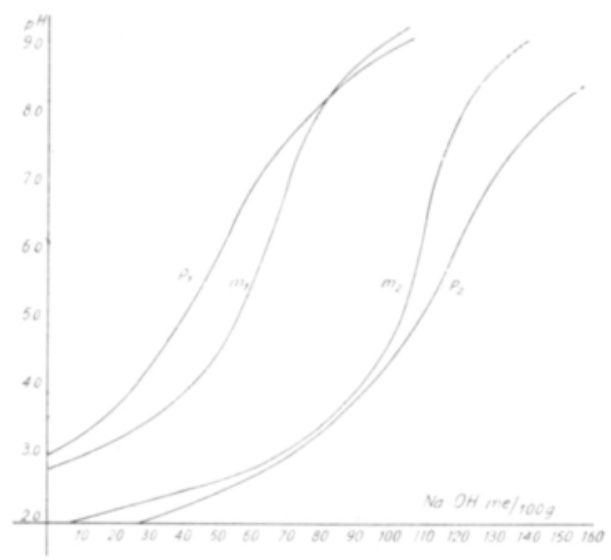

Fig. 8 Titration curves of S. Girgensohnii $(\mathrm{m})$ and of the forest Sphagnum peat $(\mathrm{p})$ constituting its. growth base.

$\begin{array}{lll} & \mathrm{S}_{T} & \mathrm{~S}_{\boldsymbol{a}} \\ \text { S. Girgensohnii } & 50 & 51 \\ \text { Forest Sphagnum peat } & 69 & 45\end{array}$

S. subfulvum with its potential difference of $10 \mathrm{mV}$ has been able to absorb from its growth base relatively much greater quantities of bases than S. Girgensohnii, which displays a potential difference of $8 \mathrm{mV}$. As has been pointed out before, this is caused by the different strengths of the acidoids in the moss and in its substrate. Another contributory factor is obviously the fact that the cations are better able to move in wet peat and are therefore more easily available than in fairly dry peat.

One of the points that caused this investigation to be undertaken was the quession: Why do different moss species thrive on different growth bases? It was assumed that the growth base is determined in the first place according to the strength of the acidoids. For instance, it was assumed that S. Warnstorfianum thrives only fn a slightly acid substrate since its acidoids are weaker than, e.g., those of S. 


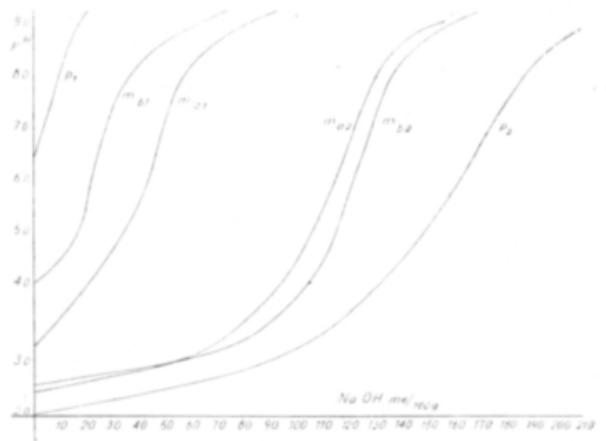

Fig. 9 Titration curves of S. fuscum $\left(\mathrm{m}_{a}\right)$ and $\mathrm{S}$. Warnstorfianum $\left(\mathrm{m}_{b}\right)$, and of the eutrophic SphagnumCarex peat $(\mathrm{p})$ constituting their growth base.

tuscum, which favours an acid growth base. The stronger the acidoids of a moss, the more strongly acid should, theoretically, be the growth from which it is able to extract all required bases. However, the results of the investigation reveal that the acidoids of all Sphagnum species are approximately equal in strength.

Another reason for the varying growth site requirements of the different Sphagnum species can be thought to lie in their different base contents. For instance, according to certain material (11) the quantity of exchangeable bases in S. Warnstorfianum was twice that of S. fuscum. S. fuscum is thus able to obtain its required bases from a more strongly acid growth base poor in bases. With an increasing base content of the substrate and at the same time an increasing $\mathrm{pH}$, the potential difference between moss and peat also increases, forcing progressively new bases to pass over from the peat into the moss. Before long this results in the unnaturally high base content of S. fuscum. According to the optimum law of growth the base optimum has by then already been passed and the bases begin to have a detrimental effect upon the growth of S. fuscum.

S. fuscum favours dry and acid growth bases although it may sometimes grow on a slightly acid substrate provided that it is dry enough. On hummocks and other slighter elevations it grows frequently also on a entrophic bog type but in such cases its substrate is more acid than the rest of the surroundings.

In gathering the material of the investigation such spots in particular were sought, where S. fuscum would grow on a base as rich in bases as possible, with the purpose of finding out how the base content of $\mathrm{S}$. fuscum is affected by high base content of the substrate. A place was indeed found where the moss grew on a substrate with a very high base content, together with $\mathrm{S}$. Warnstorfianum. The titration curves of S. fuscum and Warnstorfianum and of the underlying peat are shown in Fig. 9, while the results of the analysis can be seen from the following compilation:

$\begin{array}{lrrrcc} & \mathrm{S}_{T} & \mathrm{~S}_{a} & \mathrm{P}_{H_{2} \mathrm{O}} & \text { Ash, \% } & \mathrm{E}_{p H 7} \\ \text { S. fuscum } & 73 & 63.5 & 5.40 & 4.3 & 63 \mathrm{mV} \\ \text { S. Warnstorfianum } & 102 & 78.0 & 6.20 & 4.9 & 48 \mathrm{mV} \\ \text { Eutrophic Sphagnum-Carex peat } & 170 & 143.0 & 6.97 & 10.6 & \end{array}$

It is quite evident that the peat has a very high base content; the ash alkalinity corresponds to $2.86 \%$ pure calcium, which is $27 \%$ of the total ash quantity of the 
peat in question. The base content of S. fuscum is abnormally high, yet clearly lower than that of S. Warnstorfianum. The potential difference between S. fuscum and the peat $(63 \mathrm{mV})$ is the highest encountered in the present material. It seems therefore as if S. fuscum were able, despite its high potential difference, to control its base cation uptake in some degree (as compared with S. Warnstorfianum). It is extremely rare that $\mathrm{S}$. fuscum should grow on a substrate of such high base content (5). Under normal circumstances it should already have succumbed to such a high lime content. It is known, for instance, that the spreading of lime on a bog growing S. fuscum quite soon kills off this species, its place being taken by fen mosses. (Unpublished test results from Teuravuoma by Mr. U. Metsänheimo).

The assumption was made in connection with our working hypothesis that bases can travel in Sphagnum mosses according to the principle of cation exchange from the subterranean parts of the plant right up to its points of growth. In order to study this particular phenomenon, samples were taken of S. fuscum from the top of a very loosely knitted hummock about $40 \mathrm{~cm}$ in height and from its base, as well as from the underlying peat. The hummock was exclusively composed of S. fuscum and so loose in composition that any bases reaching the upper parts were forced to travel by route of the moss plants all the way from the peat. The compilation shown below gives the data of the analysis relating to the said samples.

$\begin{array}{cccccc} & \mathrm{S}_{T} & \mathrm{~S}_{a} & \mathrm{pH}_{\mathrm{H}_{2} \mathrm{O}} & \mathrm{pH}_{\mathrm{BaCl}} & \mathrm{E} \\ \mathrm{S} \text {. fuscum from the top of the hummock } & 27 & 28 & 4.0 & 2.8 & 58 \mathrm{mV} \\ \text { Peat from under the hummock } & 37 & 36 & 4.3 & 3.0 & 40 \mathrm{mV}\end{array}$

It can be seen from this compilation that the parts of the moss farther removed from the growth base have a distinctly lower base content than the parts closer to the substrate. This is well compatible with the assumption that the bases may travel according to the principle of cation exchange in the direction of the existing potential difference.

\section{Discussion}

The results derived from the titration curves presented in the foregoing are in agreement with the working hypothesis. The bases show a distribution between peat and moss in approximately the proportions which should obtain according to the principle of cation exchange. In watery bog types, where the cations are easily able to move owing to the presence of water, the titration curves of peat and moss in their natural state are almost coincidental. In addition to oligotrophic bogs (Fig. 5) this has been true as a rule - although there have been exceptions with regard to eutrophic, wet bogs such as, e.g., the Warnstorfianum fens. The material of investigation contained a number of samples taken from bogs of the last-mentioned type although no example of them has been given in detail. The attainment of cation equilibrium between peat and moss is promoted, except by the mobility of the cations, also by the fact that in such bog types the mosses are often submerged in water for a considerable part of their extension. The moss plants 
are then able to adsorb cations from the bog water with the aid of all their immersed parts in the same manner as the peat. Consequently no very great potential difference can come into being between the moss and the peat.

The present material of investigation seems to indicate that the potential difference between moss and peat would increase both with increasing dryness of the growth base and with its increasing trophicity. Drying naturally slows down the cation migration so that the potential difference cannot be equalized as rapidly as in the case of a watery substrate. With increasing trophicity on a fairly dry substrate the growth of the plant obviously produces new acidoids at such a high rate that it is able to raise the potential difference between the peat and the moss.

It has been noted above that the difference $\mathrm{S}_{T}-\mathrm{S}_{a}$ is greater in the peat than in the mosses. This difference has been attributed to exchangeable iron and aluminium, which would thus occur in a greater quantity in the peat than in the mosses. The exchangeable calcium, magnesium and potassium were also determined in the investigation; it was found that the exchangeable calcium quantities of moss and peat have approximately the same proportions as their ash alkalinities. The exchangeable magnesium quantities are approximately equal. On the other hand the quantity of exchangeable potassium in the moss has as a rule been about 5 to 20 times that of the peat (3). Thus, the trend of the phenomenon seems to indicate that peat and moss retain bivalent cations with about equal efficiency, whereas moss is more efficient in retaining monovalent and peat in retaining trivalent cations.

The phenomenon might be thought to be due to selective adsorption. Some experiments were performed in view of this in the laboratory with dried, finely ground moss and peat samples. It was found that at least in regard to monovalent and bivalent ions no selective adsoprtion equivalent with conditions in nature could be established. On looking for a reason to account for the selective adsorption occurring in natural conditions, one's attention is primarily drawn to the fact that in nature the adsorptive action of the mosses is limited to their parts in contact with the peat. The retained cations are therefore forced to travel in the colloidal moss system into the upper parts of the plant. It is then quite possible that monovalent ions with their small water envelope are able to move more easily in the said system than bivalent, strongly hydrated ions, which, in turn, would find it easier than the trivalent iron and aluminium ions. It is thus possible that the internal colloidal system of the moss plant favours the enrichment in itself of monovalent cations.

The calculated potential difference existing between the moss and the peat has naturally the character of a mean potential difference since it has been determined from bulk samples and not only from the boundary membranes between peat and moss. There is reason to assume that the potential with reference to the growth base increases from the boundary surfaces towards the points of growth. This thought has been substantiated by several analyses, one of which has been presented in the foregoing.

The vascular bundle of the stem lacking in Sphagnum mosses is replaced by the pith tissue, which is assumed to be serving as a nutrition transport medium. The stems have not been analysed in more detail in this investigation, so much 
was, however, done that their colloidal structure could be concluded to be approximately the same as that of the other parts of the moss. It is thus difficult to conceive that the cations might be able to travel freely with water through the colloidal pith tissue containing active hydrogen ions. It would be simpler to assume that the cations migrate from the growth base towards the points of growth, forced by the electrical potential difference, as a slow but continuous flow in accordance with the increment growth of the moss plant. Consequently, the migration of the cations would be independent of the flowing of water in the mosses. We know, for instance, that there are raised bogs in Finland with a nearly unhumified peat layer made up of S. fuscum of a thickness as great as $30 \mathrm{ft}$. (Oral report by Dr. V. Окко); in such layers the water is not able to travel, and the mosses growing on the outer surface derive their required moisture from the atmosphere. In spite of this they would be able, in accordance with the theory presented here, to obtain cations from the deeper parts of the bog, these cations travelling, forced by the potential difference, in the raw peat in stationary water.

The potential differences stated above have been calculated with the dry matter weights as a basis. In natural conditions the water content is not the same in the moss and in its growth base. A change of water content also affects the potential difference. Moreover, we do not know the volumes of the micellar solutions nor the activities of the ions. The potential difference has been calculated from the titration curves at the reaction which was measured in the laboratory from the water suspension of the fresh samples. This $\mathrm{pH}$ may be slightly different from the reaction that prevailed under natural conditions. All these factors have an influence upon the potential difference. The calculated potential differences can therefore only be considered to represent crude approximations of the actual values.

\section{$S u m m a r y$}

In the present investigation the cation uptake mechanism of Sphagnum mosses has been dealt with and a theory relating to it has been developed. In brief, the theory is as follows. In the points of growth of the Sphagnum mosses colloidal acids saturated with hydrogen ions, so-called acidoids, are continuosly formed. They produce an electrical potential difference between the moss and its growth base. The potential difference with reference to the growth base increases from the boundary surfaces between moss and peat towards the points of growth. This potential difference forces the base cations to pass over from the peat into the moss plant in the direction of the potential and at a rate controlled by it. In the investigation this potential difference has been determined experimentally with the aid of NERNST's formula.

R E F E R E N E S

(1) Drake, M., Vengris, J. \& Collby, W. G. 1951. Cation-exchange capacity of plant roots. Soil Sci. 72: $139-147$.

(2) Jenny, H. \& Overstreet, R. 1939. Cation interchange between plant roots and soil colloids. Ibid. 47: $257-272$. 
(3) KaIL , A. \& KrVekäs, J. 1956. Distribution of extractable calcium, magnesium, potassium, and sodium in various depths of some virgin peat soils. J. Sci. Agric. Soc. Finland 28; 237-247.

(4) Keller, P. \& Deuel, H. 1957. Kationenaustauschkapazität und Pektingehalt von Pflanzenwurzeln. Pflanzenernähr., Düng., Bodenkunde, 79: 119—131.

(5) Krvinen, E. 1933. Über die Reaktionsverhältnisse in den Sphagnum fuscum-Bülten. Soil Research $3,4: 195-201$.

(6) Krohn, J. 1931. Suomen rahkasammalet. Porvoo, p. 84.

(7) LUNDEgÁRDH, H. 1942. Electrochemical relations between the root system and the soil. Soil Sci. 54: 177 - 189.

(8) MalmströM, C. 1932. Degerö Stormyr. Meddelanden från Statens Skogsförs. anst. 20: 1—206.

(9) Mattson, S. \& Karlsson, N. 1944. The pedography of hydrologic soil series: VI. The composition and base status of the vegetation in relation to the soil. Ann. Agr. Coll. Sweden, 12: 186202.

(10) PAasio, I. 1935. Suomiehen sammalkirja. Helsinki, p. 68.

(11) PUUstJärvi, V. 1955. On the colloidal nature of peat-forming mosses. Arch. Soc. "Vanamo», 9: suppl: $257-272$.

$(12) \longrightarrow 1956$. On the cation exchange capacity of peats and on the factors of influence upon its formation. Acta agricult. Scand. VI, 4: 410-449.

(13) $\longrightarrow 1957$. On the status of peat soils. Ibid. 7, 2: 190-223.

\section{S E L OS T U S:}

\section{RAHKASAMMALIEN KATIONIEN OTON MEKANISMISTA}

\section{VILJO PUUSTJÄRVI}

\section{Yliopiston maanviljelyskemian laitos, Helsinki}

Tutkimuksessa on käsitelty rahkasammalien kationien ottoa turvekolloidien ja rahkasammalien välisenä kationien vaihtoilmiönä. On esitetty teoria, jonka mukaan rahkasammalien kasvupisteissä jatkuvasti muodostuvat vetyioneilla kyllästetyt kolloidiset hapot saavat rahkasammalen ja turpeen kolloidien väliselle rajapinnalle muodostumaan sähköisen jännite-eron, mikä säätelee sammalien kationien ottoa. Kyseinen jännite-ero on määritetty analyyttisesti Nernst'in kaavaa hyväksikäyttäen. Sen on todettu kohoavan suon trofian mukana. Eri rahkasammallajien erilaisen pH-vaatimuksen on katsottu aiheutuvan sammallajien erilaisista emäspitoisuuksista. Mitä korkeampi sammalen emäspitoisuus on, sitä korkeampaa emäspitoisuutta se vaatii. 